\title{
Evaluating Split Nitrogen Applications and In-Season Tests for Organic Winter Bread Wheat
}

\author{
Erin H. Roche ${ }^{1, *}$, Ellen B. Mallory ${ }^{1}$ and Heather Darby ${ }^{2}$ \\ ${ }^{1}$ University of Maine, School of Food and Agriculture, Orono, ME, USA \\ ${ }^{2}$ University of Vermont, Department of Plant and Soil Science, Burlington, VT, USA \\ * Corresponding author: E-Mail: erin.roche@maine.edu; Tel.: +1 2077453825
}

Submitted: 26 May 2016 | In revised form: 21 October 2016 | Accepted: 1 November 2016 |

Published: 13 February 2017

\begin{abstract}
Achieving high grain yields and crude protein (CP) standards in organic winter wheat (Triticum aestivum $\mathrm{L}$.) is challenging because ensuring that adequate nitrogen $(\mathrm{N})$ is available at key periods of wheat growth is difficult in organic systems. Split application regimes and in-season $\mathrm{N}$ management tests may improve organic production. In field trials conducted over four site-years in Maine and Vermont, USA, N application regimes were analyzed for their effects on organic winter wheat, $\mathrm{N}$ uptake, grain yield, and CP. Tiller density and tissue $\mathrm{N}$ tests were evaluated as in-season decision tools. Eight treatments arranged in a non-factorial design differed in terms of $\mathrm{N}$ application timing (pre-plant (PP), topdress at tillering (T1), and topdress at pre-stem extension (T2)) and $\mathrm{N}$ rate. Treatments were: (1) an untreated check, (2) pre-plant $\mathrm{N}$ at a low rate of $78 \mathrm{~kg} \mathrm{~N}^{-1}\left(\mathrm{PP}_{L}\right)$, (3) pre-plant $\mathrm{N}$ at a high rate of 117 or $157 \mathrm{~kg} \mathrm{~N}^{-1}\left(\mathrm{PP}_{H}\right),(4) \mathrm{T}_{78}$, (5) $\mathrm{PP}_{L}+\mathrm{T}_{39}$, (6) $\mathrm{PP}_{L}+\mathrm{T} 2_{39}$, (7) $\mathrm{PP}_{H}+\mathrm{T} 2_{39}$, and (8) $\mathrm{PP}_{L}+\mathrm{T} 1_{39}+\mathrm{T} 2_{39}$. Responses to $\mathrm{N}$ treatments were variable among site-years, however some common results were identified. The PP-only treatments increased grain yields more than they increased CP. The $\mathrm{T}_{78}$ and $\mathrm{PP}_{H}+\mathrm{T}_{39}$ treatments were the most effective at increasing yield and $\mathrm{CP}$, compared with the PP-only treatments. Tiller density and tissue $\mathrm{N}$ tests were good predictors of grain yield $(r=0.52, p<0.001)$ and $C P(r=0.75, p<0.001)$ respectively. Future work should test in-season decision tools using a wider range of tiller densities, and topdress $\mathrm{N}$ rates against tissue $\mathrm{N}$ measurements.
\end{abstract}

Keywords: grain crude protein; grain yield; hard red winter wheat; pre-plant N; plant N uptake

\section{Introduction}

An expanding market for locally produced bread flour in the northeastern United States has created demand for local, organic bread wheat. Economically, organic bread wheat can be a high-value crop for growers if production targets for grain yield and quality are met. Grain CP is a major indicator of quality as it dictates dough elasticity and workability [1]. On the bread wheat market, a grain CP of generally
$120 \mathrm{~g} \mathrm{~kg}^{-1}$ or greater is desired because it gives dough strength and provides loaf volume [2]. Grain with lower CP can be sold as feed but typically receives a lower price [3].

Nitrogen plays a key role in supporting both grain yield and CP in bread wheat $[4,5]$. Nitrogen not only affects grain yield components such as heads $\mathrm{m}^{-2}$, seeds head ${ }^{-1}$, and kernel size [6], but is also needed to form the proteins for baking quality [7]. Early in the season, $\mathrm{N}$ uptake tends to influence vegetative growth, and therefore grain yield 
more than protein, and these effects shift as the season progresses [8]. This relationship occurs because when $\mathrm{N}$ is available early in the season, it determines yield potential and once yield potential is set additional $\mathrm{N}$ increases grain protein content [9]. Nitrogen management systems have long been studied to determine the effects of application timing on winter wheat grain yield and CP. Woodward and Bly [4] found $165 \mathrm{~kg} \mathrm{~N} \mathrm{ha}^{-1}$ of ammonium nitrate fertilizer applied pre-plant to hard red winter wheat raised yields but not $\mathrm{CP}$, and the inverse effect was true when the application was split between fall and spring. Eilrich and Hageman [8] reported April applications of $\mathrm{N}$, as $\mathrm{Ca}\left(\mathrm{NO}_{3}\right)_{2}$, on soft red winter wheat caused a $5 \%$ grain yield increase, whereas $\mathrm{N}$ applications in May did not increase grain yield but instead increased \% grain N. A tradeoff between grain yield and CP can also occur due to factors such as limited moisture [10], cultivar, and environmental conditions [11]. As described by Fowler et al. [9], environmental or genotypic effects that increase grain yield must be met with increased amount of $\mathrm{N}$ to create a proportionally positive increase in CP. Brown and Petrie [12] found it possible to produce both high yields and acceptable CP in irrigated hard red winter wheat by providing both early-season and late-season $\mathrm{N}$, and warned of the difficulties in achieving adequate $\mathrm{CP}$ without late-season $\mathrm{N}$.

In organic cropping environments, overall $\mathrm{N}$ supply tends to be low [13-15] and the availability of $\mathrm{N}$ derived from organic sources such as animal manures and plant residues is less predictable than from inorganic sources [16]. Olesen et al. [17] reported that manure was more effective at increasing winter wheat grain yield while a grass-clover pre-crop was more effective at increasing grain protein due to differences in the timing of $\mathrm{N}$ availability. Solid animal and green manures are the most cost effective organic $\mathrm{N}$ sources but both must be applied before planting, the latter for logistical reasons and the former to reliably comply with the 90-day interval required by the National Organic Program Standards between raw manure applications and crop harvest [18]. Unfortunately wheat uptake of $\mathrm{N}$ applied at pre-plant tends to be low. Wuest and Cassman [19], for example, documented $\mathrm{N}$ recovery ranging from 30 to $55 \%$ for spring wheat. Recovery is likely lower in temperate climates because $\mathrm{N}$ in winter crops is susceptible to leaching and denitrification during the plant dormancy period [20,21]. The difficulty of ensuring late-season available $\mathrm{N}$ for winter wheat with pre-plant applications makes it challenging to achieve grain CP suitable for the bread flour market [12]. In an organic winter wheat study, Mallory and Darby [3] found that spring applied topdress $\mathrm{N}$, in addition to preplant manure, increased grain $\mathrm{CP}$ by up to 2 percentage points. While no treatments reached the $12 \% \mathrm{CP}$ milling standard in this study, had a variety with higher protein potential been used, that 2 percentage point increase might have increased CP to above $12 \%$.

In conventional bread wheat production, split applications of $\mathrm{N}$ have been shown to increase grain yield and $\mathrm{CP}$ [22]-and to improve $\mathrm{N}$ utilization efficiency or grain weight per unit-of $\mathrm{N}$ from fertilizer $[23,24]$. The general concept is to reduce fall pre-plant $\mathrm{N}$ and to add spring topdress applications at one or two critical growth periods, such as spring tillering and just prior to stem extension, Zadok growth stages (GS) 25 and 30 [25], respectively. In humid regions of the U.S., in-season diagnostic tests are used successfully to guide topdress decisions for soft winter wheat $[6,26]$. The application rate of the first split is based on tiller density at GS25 whereas the second split is based on tissue $\mathrm{N}$ concentration at GS30. Low tiller density $(<1000$ tillers $\mathrm{m}^{-2}$ ) indicates some or all fertilizer $\mathrm{N}$ application at GS25 is needed immediately to increase tiller numbers to support grain yields [20]. Alternatively, high tiller density $\left(>1000\right.$ tillers $\mathrm{m}^{-2}$ ) indicates additional $\mathrm{N}$ is not needed until GS30. Next, wheat tissue N at GS30 is used to assess crop fertilizer $\mathrm{N}$ requirements just prior to the period of highest $\mathrm{N}$ uptake [25] and has been identified as a beneficial indicator of the topdress rates needed to maximize yields in soft wheat systems. In Virginia, for example, Baethgen and Alley [26] identified $39.5 \mathrm{~g} \mathrm{~kg}^{-1}$ as the critical tissue $\mathrm{N}$ concentration at GS30 to achieve $90 \%$ of the maximum grain yield.

Few studies have analyzed split application regimes for organic winter wheat production [3] and to our knowledge none have used the in-season decision tools under organic conditions. The adoption of these practices by farmers has the potential to reduce $\mathrm{N}$ loss to the environment and increase the value of bread wheat through enhancing yield and quality. The objectives of this study were to: 1) evaluate the effects of pre-plant and split application treatments on grain $\mathrm{N}$ uptake, yield, and $\mathrm{CP}$, on organic hard red winter wheat; and to 2) assess the potential of in-season tests to optimize grain yield and grain CP.

\section{Materials and Methods}

\subsection{Study Site and Experimental Design}

The field experiment was conducted in 2012 and 2013 in Maine (ME) and Vermont (VT). In ME, the site was a certified organic field (MOFGA Certification Services, LLC) at the University of ME Rogers Farm Forage and Crop Research Facility $\left(44^{\circ} 56^{\prime} \mathrm{N}, 68^{\circ} 42^{\prime} \mathrm{W}\right)$ in Old Town. The site was converted to organic production in 2007 . The soil was a Melrose fine silt loam (coarse-loamy over clayey, mixed illitic, superactive, frigid Oxyaquic Dystrudepts) with a pH of $6.2,3.3 \%$ organic matter, $11.8 \mathrm{~kg} \mathrm{ha}^{-1}$ soil test phosphorus ( $P$ ) by Modified Morgan, $547 \mathrm{~kg} \mathrm{ha}^{-1}$ soil test potassium (K), and $23 \mathrm{~kg} \mathrm{ha}^{-1}$ soil test sulfur (S) based on $2,241,702 \mathrm{~kg} \mathrm{ha}^{-1}$ of soil in a plow layer (16.9 cm deep), as determined per the standard methods of the ME Soil Testing Service. In ME, the 2012 experiment was preceded by a season of tilled fallow to control perennial weeds and was planted to corn silage (Zea mays L.) in 2010. Immediately following winter wheat harvest a cover crop of mustard (Sinapis arvensis 'Ida Gold') was established and allowed to grow for 4 weeks. It was then incorporated into the soil 
two weeks before the 2013 experiment was initiated. The 2013 experiment was initiated in the same field in an area adjacent to the 2012 experiment that, in 2012, was cropped with winter wheat. The VT experiments were located at

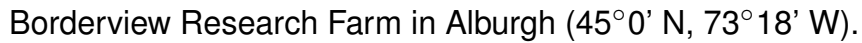
In 2012, the soil was a Benson Rocky silt loam (loamyskeletal, mixed, active, mesic Lithic Eutrudepts) with a $\mathrm{pH}$ of $6.9,3.8 \%$ organic matter, $4.5 \mathrm{~kg} \mathrm{ha}^{-1}$ soil test $\mathrm{P}$ (Modified Morgan), $81.8 \mathrm{~kg} \mathrm{ha}^{-1}$ soil test $\mathrm{K}$, and $20.2 \mathrm{~kg} \mathrm{ha}^{-1}$ soil test $\mathrm{S}$, determined as above. The prior crops were winter wheat and no-till sunflowers (Helianthus annuus L.) in 2011 and 2010, respectively. In 2013, the soil was a Benson Rocky silt loam (loamy-skeletal, mixed, active, mesic Lithic Eutrudepts) with a pH of 7.5, 5.2\% organic matter, 9.6 $\mathrm{kg} \mathrm{ha}^{-1}$ soil test $\mathrm{P}$ (Modified Morgan), $90.7 \mathrm{~kg} \mathrm{ha}^{-1}$ soil test $\mathrm{K}$, and $22.4 \mathrm{~kg} \mathrm{ha}^{-1}$ soil test $\mathrm{S}$, determined as above. The prior crop was spring wheat and this site had been in grass-legume sod for 14 to 15 years before being converted to annual cropping of minimum-tilled sunflowers in 2011.

Field plots were $1.8 \mathrm{~m}$ by $13.4 \mathrm{~m}$, arranged in a randomized complete block design with four replications. Treatments were designed to evaluate the effectiveness of different $\mathrm{N}$ application options that organic farmers in the northeastern region would use to influence grain yield and CP. Table 1 provides a description of the treatments, which differed in terms of $\mathrm{N}$ application timing and $\mathrm{N}$ rates, but which were not a factorial arrangement of these two factors. Treatments differed in terms of total available $\mathrm{N}$ applied depending on pre-plant $\mathrm{N}$ application rate and whether topdress applications were made. The different $\mathrm{N}$ application timings were pre-plant (PP), topdress at tillering or Zadok 25 (T1), and topdress at stem elongation or Zadok 30 (T2). Dairy manure (Bos taurus) was used as the pre-plant $\mathrm{N}$ source to reflect the fact that farmers in the northeastern region and elsewhere rely on manure and green manures for pre-plant applications. The target rates for the pre-plant timing were 78 and $117 \mathrm{~kg} \mathrm{ha}^{-1}$ of available $\mathrm{N}$, with the exception of VT-2013 where a high rate of $157 \mathrm{~kg} \mathrm{ha}^{-1}$ of available $\mathrm{N}$ was used. The $\mathrm{PP}_{L}$ was chosen to represent the standard practice for organic hard red winter wheat in the area. Solid dairy manure was used in ME-2012, ME2013, and VT-2013, and composted solid dairy manure was used in VT-2012. Estimated available $\mathrm{N}$ for dairy manure was calculated as $25 \%$ of the total organic N [27] and 40 $50 \%$ of the total inorganic $\mathrm{N}[28,29]$ with a limit of $11.2 \mathrm{~kg}$ inorganic $\mathrm{N} \mathrm{ha}^{-1}$ assuming anything greater was lost over the winter. This limit was based on prior organic winter wheat research conducted over four site-years where the difference in crop $\mathrm{N}$ uptake in the early spring at tillering between the pre-plant dairy manure treatment and a no-N check was on average only $7 \mathrm{~kg} \mathrm{ha}^{-1}$ and never exceeded $10 \mathrm{~kg} \mathrm{ha}^{-1}$ at any individual site-year. Organic producers in ME and VT have a limited window in the springtime to apply manure due to soil conditions and the National Organic Program 90-day rule [18]. Chilean nitrate (CN) was used because it was the preferred $\mathrm{N}$ source for topdressing among regional farmers at the time of trial initiation and it was not feasible to use the same pre-plant materials for topdressing. Chilean nitrate is also the least expensive per unit $\mathrm{N}$ of allowable materials that is accessible to farmers in ME and VT. The CN topdress $\mathrm{N}$ source is a mined sodium nitrate product (16-0-0) that was approved for use at the time of trial initiation under organic certification in the USA to supply up to $20 \%$ of crop $\mathrm{N}$ needs [30]. The CN rates in this study exceeded the $20 \%$ limit in some plots for experimental purposes.

Table 1. Treatment descriptions for organic winter wheat $\mathrm{N}$ management study conducted in Maine (ME) and Vermont (VT) in 2012 and 2013.

\begin{tabular}{|c|c|c|c|c|}
\hline \multirow[b]{2}{*}{ Treatment } & \multicolumn{4}{|c|}{ Topdress $\mathrm{N}$ rate $\nmid\left(\mathrm{kg} \mathrm{ha}^{-1}\right)$} \\
\hline & $\begin{array}{l}\text { Pre-plant }(\mathrm{PP}) \text { manure } \\
\text { target total available N } \\
\text { rate }\end{array}$ & GS25 $\ddagger$ Tillering (T1) & $\begin{array}{l}\text { GS30 } \ddagger \text { Pre-stem } \\
\text { extension (T2) }\end{array}$ & $\begin{array}{l}\text { Total estimated available } \\
\mathrm{N} \text { applied }\end{array}$ \\
\hline Check & 0 & 0 & 0 & 0 \\
\hline $\mathrm{PP}_{L}$ & 78 & 0 & 0 & 78 \\
\hline $\mathrm{PP}_{H}$ & $117 \S$ & 0 & 0 & 1179 \\
\hline $\mathrm{T} 1_{78}$ & 0 & 78 & 0 & 78 \\
\hline $\mathrm{PP}_{L}+\mathrm{T}_{39}$ & 78 & 39 & 0 & 117 \\
\hline $\mathrm{PP}_{L}+\mathrm{T}_{39}$ & 78 & 0 & 39 & 117 \\
\hline $\mathrm{PP}_{H}+\mathrm{T}_{39}$ & $117 \S$ & 0 & 39 & 1569 \\
\hline $\mathrm{PP}_{L}+\mathrm{T}_{1} 1_{39}+\mathrm{T} 2_{39}$ & 78 & 39 & 39 & 156 \\
\hline \multicolumn{5}{|c|}{$\dagger$ Applied as Chilean nitrate. } \\
\hline \multicolumn{5}{|c|}{$\ddagger$ Zadoks scale for growth staging cereals [25]. } \\
\hline \multicolumn{5}{|c|}{$\S$ Pre-plant N rate was $157 \mathrm{~kg} \mathrm{ha}^{-1}$ in VT-2013. } \\
\hline
\end{tabular}




\subsection{Management Practices}

Prior to experiment initiation, one composite soil sample was collected from each trial location to verify adequate $\mathrm{P}, \mathrm{K}$, and S levels [31]. Dates of field operations, topdress applications, and sampling are provided by site-year in Table 2. In ME, one day before wheat seeding, manure was applied by hand and incorporated within 4 hours using a Perfecta $($ II Field Cultivator (Unverferth Manufacturing Co, Inc. Kalida, OH, USA). In VT, manure was applied

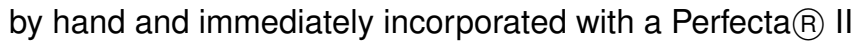
Field Cultivator on the same day as wheat seeding. Manure application rates are presented in Table 3.

Plots that did not receive pre-plant manure were not amended with $\mathrm{P}$ and $\mathrm{K}$ because soils had adequate nutrient levels, based on pre-plant soil testing. In ME, hard red winter wheat (variety AC Morley) was seeded at a density of 350 viable seeds $\mathrm{m}^{-2}$ and row spacing of $17.7 \mathrm{~cm}$ using an Almaco cone seeder with double-disk openers (Almaco Inc., Nevada, IA, USA) after which plots were packed with a Brillion $1.5 \mathrm{~m}$ Sure Stand grass seeder (Landoll Co., Marysville, KS, USA). In VT, hard red winter wheat (variety Harvard) was seeded at a rate of 335 viable seeds $\mathrm{m}^{-2}$ in 2012 and 306 viable seeds $\mathrm{m}^{-2}$ in 2013 with a Sunflower 94123.0 $\mathrm{m}$ grain drill (Sunflower Manufacturing, Beloit, KS, USA) double disc opener outfitted with a row spacing of $17.8 \mathrm{~cm}$. Topdress $\mathrm{N}$ applications were applied by hand at wheat developmental stages on dates outlined in Table 2 and at rates indicated in Table 3.

Table 2. Summary of field operations, topdress applications, and biomass sampling in the organic winter wheat $\mathrm{N}$ management study conducted in Maine (ME) and Vermont (VT) in 2012 and 2013.

\begin{tabular}{llllll}
\hline Operation & Wheat growth stage $\dagger$ & ME-2012 & ME-2013 & VT-2012 & VT-2013 \\
\hline Manure application, PP $\ddagger$ & - & 19 Sept 2011 & 14 Sept 2012 & 27 Sept 2011 & 24 Sept 2012 \\
Wheat seeding & - & 20 Sept 2011 & 15 Sept 2012 & 27 Sept 2011 & 24 Sept 2012 \\
Wheat biomass sampling no. 1 & Tillering, GS25 & 19 Apr & 30 Apr & 12 Apr & 19 Apr \\
Topdress N application, T1 & Tillering, GS25 & $20 \mathrm{Apr}$ & 30 Apr & 12 Apr & 19 Apr \\
Wheat biomass sampling no. 2 & Pre-stem extension, GS30 & 30 Apr & 13 May & 26 Apr & 03 May \\
Topdress N application, T2 & Pre-stem extension, GS30 & 02 May & 13 May & 26 Apr & 03 May \\
Wheat biomass sampling no. 3 3 & Soft dough, GS85 & 06 Jul & 03 Jul & 02 Jul & 09 Jul \\
Wheat harvest & Maturity, GS93 & 25 Jul & 1 Aug & 11 Jul & 19 Jul \\
\hline
\end{tabular}

$\dagger$ Zadoks scale for growth staging cereals [25].

$\ddagger$ PP, pre-plant; T1, topdress at tillering; and T2, topdress at pre-stem extension.

Table 3. Material and nutrient application rates for $\mathrm{N}$ sources applied as pre-plant and topdress to winter wheat in Maine (ME) and Vermont (VT) in 2012 and 2013.

\begin{tabular}{|c|c|c|c|c|c|c|c|c|c|c|}
\hline \multirow{3}{*}{$\begin{array}{l}\text { Material and nutrient application } \\
\text { rates }\end{array}$} & \multicolumn{8}{|c|}{ Pre-plant manure target $\mathrm{N}$ rate $\dagger$} & & \\
\hline & \multicolumn{2}{|c|}{ ME-2012 } & \multicolumn{2}{|c|}{ ME-2013 } & \multicolumn{2}{|c|}{ VT-2012 } & \multicolumn{2}{|c|}{ VT-2013 } & \multicolumn{2}{|c|}{$\begin{array}{l}\text { Topdress } \\
\text { Chilean nitrate } \\
\text { target } \mathrm{N} \text { rate† }\end{array}$} \\
\hline & 78 & 117 & 78 & 117 & 78 & 117 & 78 & 157 & 39 & 78 \\
\hline Dry matter (\%) & \multicolumn{2}{|c|}{28.3} & \multicolumn{2}{|c|}{26.6} & \multicolumn{2}{|c|}{19.8} & \multicolumn{2}{|c|}{20.2} & & \\
\hline Material $\left(\mathrm{Mg} \mathrm{ha}^{-1}\right)$ & 72 & 108 & 56 & 84 & 45 & 67 & 40 & 74 & 0.25 & 0.49 \\
\hline Organic N (kg ha $\left.{ }^{-1}\right)$ & 260 & 390 & 193 & 290 & 275 & 412 & 307 & 563 & 0 & 0 \\
\hline Inorganic N $\left(\mathrm{kg} \mathrm{ha}^{-1}\right)$ & 46 & 68 & 25 & 38 & 32 & 48 & 23 & 42 & 39 & 78 \\
\hline Estimated available $\mathrm{N} \ddagger\left(\mathrm{kg} \mathrm{ha}^{-1}\right)$ & 76 & 109 & 59 & 84 & 80 & 114 & 86 & 152 & 39 & 78 \\
\hline Total P $\left(\mathrm{kg} \mathrm{ha}^{-1}\right)$ & 150 & 224 & 173 & 259 & 91 & 137 & 73 & 134 & 0 & 0 \\
\hline Total K (kg ha $\left.{ }^{-1}\right)$ & 286 & 429 & 325 & 488 & 154 & 232 & 101 & 184 & 0 & 0 \\
\hline
\end{tabular}

$\dagger$ Estimated available $\mathrm{N}\left(\mathrm{kg} \mathrm{ha}^{-1}\right)$.

$\ddagger$ Estimated available $\mathrm{N}$ was calculated as $25 \%$ of the total organic-N [27] and $40-50 \%$ of the total inorganic $\mathrm{N}$ for dairy manure [27-29] with a limit of $11.2 \mathrm{~kg}$ inorganic $\mathrm{N} \mathrm{ha}^{-1}$. 


\subsection{Measurements and Analytical Procedures}

Tiller density was determined at tillering for the PP-only treatments by counting wheat shoots with three or more leaves in eight $0.3-\mathrm{m}$ sections of row per plot. These treatments were sampled to measure pre-plant $\mathrm{N}$ effects on tillering because all other $\mathrm{N}$ applications came at or after tillering. Leaf tissue $\mathrm{N}$ concentration at pre-stem extension was measured via destructive sampling that took place in one half of each plot. Plants were clipped at $2 \mathrm{~cm}$ from the soil surface from three $0.3-\mathrm{m}$ sections of rows (avoiding border rows). On consecutive sampling dates, sample areas were positioned $0.3 \mathrm{~m}$ away from the preceding sample area. Samples were bulked to represent a total sample area of $0.9 \mathrm{~m}$ of row per plot. Plants were dried at $60^{\circ}$ $\mathrm{C}$, weighed, and ground through a 2-mm mesh. Total $\mathrm{N}$ concentration was determined by combustion for a 250-mg subsample using a Leco CN2000 analyzer (Leco Corp., St. Joseph, MI, USA) in ME, whereas in VT, a 100-gram sample was submitted to Cumberland Valley Analytical Services (Hagerstown, MD, USA), for Near Infrared Reflectance spectroscopy. Plant N uptake by wheat and weed biomass was determined at three wheat developmental stages: tillering, pre-stem extension, and soft dough (GS85, or "peak biomass")-all using the same methods as for leaf tissue $\mathrm{N}$ sampling. Weed pressure was very low so no weed control measures were taken. Weed samples were collected from the sample area and included in plant $\mathrm{N}$ calculations when weed biomass composed $>2 \%$ of the total plant biomass. Plant $\mathrm{N}$ uptake was calculated by multiplying plant above ground biomass by $\% \mathrm{~N}$. At soft dough, the number of spikes per bulk sample was counted and recorded.

Grain was harvested between 25 July and 1 August from a $1.5 \mathrm{~m}$ by $9.1 \mathrm{~m}$ harvest area with a Wintersteiger small-plot combine (Ried, AT) in ME, and between 11 and 19 July, from a $1.4 \mathrm{~m}$ by $5.5 \mathrm{~m}$ harvest area with a Almaco SPC50 plot combine (Almaco, Inc., Nevada, IA, USA) in VT. Grain was cleaned with a small Clipper (Clipper, A.T. Ferrell Co., Bluffton, IN, USA) to remove weed seeds and inert material. Grain samples were weighed. Moisture was measured (GAC 2100, DICKEY-john Corp., Auburn, IL, USA) and adjusted to $135 \mathrm{~g} \mathrm{~kg}^{-1}$ on cleaned samples to determine grain yield. Grain was subsampled $(100 \mathrm{~g})$ and ground (2 $\mathrm{mm}$ mesh). In ME, grain CP was determined on a 250 -mg sub-subsample by multiplying Leco $\mathrm{N}$ by 5.7 $\mathrm{N}$, according to American Association of Cereal Chemists (AACC) method 46-30.01 [32], and adjusted to $120 \mathrm{~g} \mathrm{~kg}^{-1}$ grain moisture. In VT, grain CP was determined on a 250mg sub-subsample using a Perten Inframatic 8600 Flour Analyzer (PertenElmer Co., Hägersten, SWE). Combustion and NIR techniques are both accepted methods for $\mathrm{CP}$ determination [33]. Thousand kernels weights (TKW) were collected in ME. One thousand seeds per plot were counted using a seed counter (Count-A-Pak Seed Totalizer, Seedburo Equipment Co., Des Plaines, IL, USA), weighed, and adjusted to $135 \mathrm{~g} \mathrm{~kg}^{-1}$ moisture. Weather data were collected at these research sites unless otherwise noted.

\subsection{Statistical Analysis and Calculations}

Data were analyzed with the statistical program $R$ [34] using a mixed model Analysis of Variance (ANOVA) with block as a random effect and treatment and site-year as fixed effects. The "nlme" package [35] was used to test the significance of site-year, treatment, and site-year by treatment interactions. The ANOVA assumption of equal variance was verified with Levene's test using the 'car' package [36]. Residual values were used to assess normal distribution with the Shapiro-Wilk Normality test. When residuals did not conform to equal variances and normality, a Box-Cox power transformation was used using the 'MASS' package [37]. The treatments were arranged in an incomplete factorial to test only treatments of specific interest to farmers in the region. The data were analyzed with a means separation using Fisher's Protected Least Significant Difference (LSD) using the 'multcomp' package [38]. Plant N uptake effects were analyzed by date as not all treatments were measured at every date thereby precluding a repeated measures analysis. Grain N yield was determined by multiplying grain $\mathrm{N}(\%)$ by grain yield $\left(\mathrm{kg} \mathrm{ha}^{-1}\right)$. The difference method was used to calculate apparent nitrogen recovery (ANR) for PP-only treatments by subtracting the plant $\mathrm{N}$ uptake of the check treatment from the plant $\mathrm{N}$ uptake of the PP-only treatments divided by the estimated amount of plant available $\mathrm{N}$ applied pre-plant [39]. Apparent nitrogen recovery was similarly calculated for topdress treatments by subtracting the plant $\mathrm{N}$ uptake of the PP-only treatments from the plant $\mathrm{N}$ uptake of the topdress treatment divided by the estimated amount of plant available $\mathrm{N}$ applied at topdress. Coefficient of variation (CV) was calculated as a function of square root of error mean square divided by the site-year mean for each response variable. In-season test data were analyzed with linear regression using treatment means over site-years because the tests should show relationships between variables over a range of sites, seeding rates, and varieties. These analyses were used to determine the correlations between: 1) grain yield and tiller density at GS25, 2) grain yield and tissue N concentration at GS30, and 3) $\mathrm{CP}$ and tissue $\mathrm{N}$ concentration at GS30.

\section{Results}

\subsection{Weather}

Monthly mean temperature and precipitation amounts for the four site-years are presented in Table 4. During seeding and pre-plant applications in September, all site-years except ME-2012 experienced greater than the 30-year normal precipitation. In VT-2012 approximately $24 \mathrm{~mm}$ of rainfall occurred 2 days after the pre-plant application and could have caused $\mathrm{N}$ leaching. For all site-years, March was warmer than average and there was a period of drier than average weather beginning in March and extending through April. The VT-2013 site-year experienced wetter than normal precipitation during the months of May and June but 
the majority of rainfall occurred at least a week after the T2 treatment application. In July, weather conditions turned dry, especially in ME-2012 and VT-2013 when rainfall was 65 and $59 \mathrm{~mm}$ less than the 30-year average, respectively.

Table 4. Monthly mean air temperature measured at $1.5 \mathrm{~m}$ from the ground, rainfall from September through November of the seeding year and from March through July of the harvest year at the experiment sites in Maine (ME) and Vermont (VT) compared with average climate data for 1981 to 2010 .

\begin{tabular}{|c|c|c|c|c|c|c|}
\hline & \multicolumn{3}{|c|}{ Maine } & \multicolumn{3}{|c|}{ Vermont } \\
\hline & 2012 & 2013 & 30-year aver. & 2012 & 2013 & 30-year aver. \\
\hline Month & \multicolumn{6}{|c|}{ Mean temperature $\left({ }^{\circ} \mathrm{C}\right)$} \\
\hline September $\dagger$ & 16.1 & 13.5 & 13.9 & 17.1 & 16 & 16.1 \\
\hline October† & 9.4 & 9.8 & 7.8 & 10.1 & 11.3 & 8.9 \\
\hline November† & 5.0 & 0.7 & 2.2 & 6.3 & 3.1 & 3.9 \\
\hline March & 2.3 & 0.3 & -1.4 & 4.3 & 0.1 & -0.6 \\
\hline April & 6.8 & 5.1 & 5.3 & 7.2 & 6.4 & 7.2 \\
\hline May & 12.7 & 11.9 & 11.4 & 15.8 & 15.1 & 13.3 \\
\hline June & 15.9 & 16.9 & 16.4 & 19.4 & 17.8 & 18.9 \\
\hline \multirow[t]{2}{*}{ July } & 20.0 & 20.8 & 19.7 & 21.9 & 22.1 & 21.7 \\
\hline & \multicolumn{6}{|c|}{ Rainfall (mm) } \\
\hline September† & 48 & 204 & 96 & 141 & 136 & 91 \\
\hline Octobert & 109 & 179 & 101 & 89 & 105 & 91 \\
\hline November† & 66 & 40 & 112 & 36 & 17 & 79 \\
\hline March & 50 & 66 & 104 & 38 & 26 & 56 \\
\hline April & $93 \ddagger$ & 36 & 96 & 67 & 54 & 71 \\
\hline May & 109 & 107 & 99 & 99 & 122 & 89 \\
\hline June & 153 & 152 & 103 & 82 & $234 \S$ & 94 \\
\hline July & 25 & 112 & 90 & 96 & 48 & 107 \\
\hline
\end{tabular}

† Seeding year.

$\ddagger$ Precipitation data was not available for 26 April 2012 in ME.

$\S$ June 2013 precipitation data for the VT site was taken from the National Weather Service, South Hero, VT $\left(44.65^{\circ} \mathrm{N} 73.31^{\circ} \mathrm{W}\right)$.

\subsection{Plant Nitrogen Uptake}

Plant $\mathrm{N}$ uptake data were analyzed over site-years (Table 5). In ME-2013, weeds comprised $6 \%$ of aboveground biomass at the soft dough stage and $11 \%$ of total plant $\mathrm{N}$ uptake, and thus weed $\mathrm{N}$ uptake was included in plant $\mathrm{N}$ uptake (Table 5). However, there were no significant differences among treatments in either weed biomass or weed $N$ uptake ( $p$ $=0.157$ and 0.132 , respectively; data not shown). In all other site-years, weed biomass never exceeded $2 \%$ of the aboveground biomass, thus plant $\mathrm{N}$ uptake reported in the results directly represents wheat $\mathrm{N}$ uptake.

The PP-only treatments $\left(\mathrm{PP}_{L}\right.$ and $\left.\mathrm{PP}_{H}\right)$ generally did not increase $\mathrm{N}$ uptake compared with the untreated check.
The exception was in ME-2012 at tillering when the $\mathrm{PP}_{L}$ treatment increased $\mathrm{N}$ uptake by 7.1 and $4.6 \mathrm{~kg} \mathrm{~N} \mathrm{ha}^{-1}$ compared with the check and $\mathrm{PP}_{H}$ treatments, respectively. Delaying all $\mathrm{N}$ applications until tillering $\left(\mathrm{T}_{78}\right)$ increased plant $\mathrm{N}$ uptake at soft dough by $48.4 \mathrm{~kg} \mathrm{~N}^{-1}$ compared with applying the equivalent amount of $\mathrm{N}$ at pre-plant $\left(\mathrm{PP}_{L}\right)$.

The $\mathrm{PP}_{L}+\mathrm{T}_{39}$ treatment consistently increased $\mathrm{N}$ uptake compared with the PP-only treatments, and uptake was on average $20 \%$ and $28 \%$ greater at pre-stem extension and at soft dough, respectively. Topdressing supplemental $\mathrm{N}$ at pre-stem extension $\left(\mathrm{PP}_{L}+\mathrm{T}_{39}\right.$ and $\mathrm{PP}_{H}+$ $\mathrm{T}_{39}$ ) increased plant accumulated $\mathrm{N}$ compared with their respective PP-only treatments, by an average of $30 \%$. Topdressing twice $\left(\mathrm{PP}_{L}+\mathrm{T}_{39}+\mathrm{T} 2_{39}\right)$ resulted in $\mathrm{N}$ uptake at soft dough that was similar to the $\mathrm{PP}_{L}+\mathrm{T}_{39}$ and $\mathrm{PP}_{L}+$ $\mathrm{T} 2_{39}$ treatments but greater than $\mathrm{PP}_{H}+\mathrm{T} 2_{39}$ by $27.5 \mathrm{~kg} \mathrm{~N}$ $\mathrm{ha}^{-1}$. Apparent $\mathrm{N}$ recovery rates of the PP-only treatments were the lowest among all treatments and were $15 \%$ on average (data not shown). The ANR of topdress treatments ranged from 60 to $89 \%$. Both the $\mathrm{T}_{78}$ and $\mathrm{PP}_{L}+\mathrm{T} 2_{39}$ treatments had ANR values greater than $80 \%$.

\subsection{Tiller and Spike Densities}

Due to significant treatment by site-year interactions for tiller density, spike density, and the other response variables listed in Table 6, the data were analyzed and are presented by site-year (Table 7). Tiller densities averaged 1371, 738, 906, and 890 tillers $\mathrm{m}^{-2}$ in ME-2012, ME-2013, VT-2012, and VT-2013, respectively, and were not influenced by PPonly treatments (data not shown).

The PP-only treatments also did not influence spike density except in ME-2013, where the $\mathrm{PP}_{L}$ treatment produced $38 \%$ more spikes than the check. The addition of topdress $\mathrm{N}$ increased spike density in most cases in ME-2012; $\mathrm{T}_{78}$ vs. $\mathrm{PP}_{L}$, and $\mathrm{PP}_{L}+\mathrm{T}_{1}$ vs. $\mathrm{PP}_{L}$, and $\mathrm{PP}_{L}+\mathrm{T}_{39}+\mathrm{T}_{39}$ vs. $\mathrm{PP}_{L}+\mathrm{T}_{29}$ treatments increased spike density by 48 , 47 , and $34 \%$, respectively. In ME-2013 and VT-2013, the $\mathrm{PP}_{L}+\mathrm{T}_{39}+\mathrm{T} 2_{39}$ treatment also increased spike density relative to the $\mathrm{PP}_{L}+\mathrm{T} 1_{39}$ treatment by 25 and $43 \%$, respectively. Spike densities were unaffected by treatments in VT-2012, which had higher \%CV than the other site years (Table 7).

\subsection{Grain Yield}

Average grain yields by site-year were 5.22, 2.41, 3.09, and $4.44 \mathrm{Mg} \mathrm{ha}^{-1}$ for ME-2012, ME-2013, VT-2012, and VT-2013, respectively (Table 7). Yields in ME-2013 and VT-2012 were approximately 1.08 and $1.63 \mathrm{Mg} \mathrm{ha}^{-1}$ lower, respectively, than average yields from trials conducted with the same varieties and locations in those years whereas VT-2013 average grain yields were $0.57 \mathrm{Mg} \mathrm{ha}^{-1}$ higher than the local equivalent [40]. 
Table 5. Mixed model ANOVA and LSD results of mean plant $\mathrm{N}$ uptake for wheat at different growth stages as affected by pre-plant and topdress N treatments in Maine (ME) and Vermont (VT) in 2012 and 2013. Treatment means presented are the means of the 4 site-years.

\begin{tabular}{|c|c|c|c|c|c|c|}
\hline \multirow[b]{2}{*}{ Effects and sources of variation } & \multicolumn{6}{|c|}{ Plant N Uptake $\left(\mathrm{kg} \mathrm{N} \mathrm{ha}^{-1}\right)$} \\
\hline & & Tillering & & Pre-stem extension & & Soft dough \\
\hline \multicolumn{7}{|l|}{ Site-year } \\
\hline ME2012 & & $41.5 \dagger$ & & 37.1 & & 73.4 \\
\hline ME2013 & & 10.5 & & 26.8 & & 91.1 \\
\hline VT2012 & & 31.9 & & 47.4 & & 125 \\
\hline VT2013 & & 18 & & 51.8 & & 231 \\
\hline \multicolumn{7}{|l|}{ Treatment } \\
\hline Check & & $22.3^{a} \ddagger$ & & $34.6^{a}$ & & $93.7^{a}$ \\
\hline $\mathrm{PP}_{L} \dagger$ & & $29.4^{b}$ & & $39.2^{a b}$ & & $111.7^{a b}$ \\
\hline $\mathrm{PP}_{H}$ & & $24.8^{a}$ & & $39.5^{a b}$ & & $102.2^{a}$ \\
\hline $\mathrm{T}_{78}$ & & - & & $43.3^{b c}$ & & $160.1^{e}$ \\
\hline $\mathrm{PP}_{L}+\mathrm{T}_{39}$ & & - & & $47.3^{c}$ & & $136.7^{c d}$ \\
\hline $\mathrm{PP}_{L}+\mathrm{T} 2_{39}$ & & - & & - & & $146.6^{c e}$ \\
\hline $\mathrm{PP}_{H}+\mathrm{T}_{39}$ & & - & & - & & $131.2^{b c}$ \\
\hline $\mathrm{PP}_{L}+\mathrm{T}_{39}+\mathrm{T} 2_{39}$ & & - & & - & & $158.7^{d e}$ \\
\hline Sources of variation & df & F-value & $\mathrm{df}$ & F-value & $\mathrm{df}$ & F-value \\
\hline Site-year (S) & 3 & $35.9^{\star \star \star}$ & 3 & $21.6^{\star \star \star}$ & 3 & $32.2^{\star \star \star}$ \\
\hline Treatment $(T)$ & 2 & $6.8^{* *}$ & 4 & $5.8^{* * *}$ & 7 & $9.1^{* * *}$ \\
\hline $\mathrm{S} \times \mathrm{T}$ & 6 & 1.62 & 12 & 1.01 & 21 & 1.03 \\
\hline CV, \% & & 19.2 & & 16.9 & & 24.0 \\
\hline
\end{tabular}

* Significant at $\mathrm{P}<0.05 ;{ }^{* *}$ Significant at $\mathrm{P}<0.01$; ** Significant at $\mathrm{P}<0.001$.

$\dagger \mathrm{PP}_{L}, 78 \mathrm{~kg} \mathrm{~N}$ ha $^{-1}$ manure at pre-plant; $\mathrm{PP}_{H}, 117$ or $157 \mathrm{~kg} \mathrm{~N} \mathrm{ha}^{-1}$ manure at pre-plant; $\mathrm{T}_{78}, 78 \mathrm{~kg} \mathrm{~N} \mathrm{ha}^{-1}$ topdress at tillering; $\mathrm{T}_{39}, 39 \mathrm{~kg} \mathrm{~N}$ ha $^{-1}$ topdress at tillering; $\mathrm{T}_{39}, 39 \mathrm{~kg} \mathrm{~N} \mathrm{ha}^{-1}$ topdress at pre-stem extension.

$\ddagger$ Within column and site-year, treatment means with the same lower case letter are not significantly different at $\mathrm{P}<0.05$.

Table 6. Mixed model ANOVA results of mean spike density, grain yield, GS30 tissue N, grain crude protein, and grain N yield for wheat as affected by pre-plant and topdress N treatments in Maine (ME) and Vermont (VT) in 2012 and 2013.

\begin{tabular}{|c|c|c|c|c|c|c|c|c|c|c|}
\hline \multirow[t]{2}{*}{ Sources of variation } & \multicolumn{2}{|c|}{ Spike density } & \multicolumn{2}{|c|}{ Grain yield } & \multicolumn{2}{|c|}{ GS30 tissue $\mathrm{N}$} & \multicolumn{2}{|c|}{ Grain crude protein } & \multicolumn{2}{|c|}{ Grain $N$ yield } \\
\hline & df & F-value & df & F-value & df & F-value & df & F-value & df & F-value \\
\hline Site-year (S) & 3 & $4.7^{*}$ & 3 & $67.5^{\star \star \star}$ & 3 & $33.6^{\star * *}$ & 3 & $86.2^{\star \star \star}$ & 3 & $69.3^{\star \star \star}$ \\
\hline Treatment $(\mathrm{T})$ & 7 & $6.0^{\star \star \star}$ & 7 & $8.7^{* \star *}$ & 4 & $31.5^{\star \star *}$ & 7 & $13.0^{\star \star \star}$ & 7 & $14.8^{* \star *}$ \\
\hline$S \times T$ & 21 & $2.1^{\star \star}$ & 21 & $2.8^{* * *}$ & 21 & $2.7^{\star *}$ & 21 & $1.8^{\star}$ & 21 & $3.2^{* * *}$ \\
\hline $\mathrm{CV}, \%$ & & 17.0 & & 12.7 & & 7.2 & & 4.2 & & 12.7 \\
\hline
\end{tabular}

* Significant at $\mathrm{P}<0.05$; ${ }^{*}$ Significant at $\mathrm{P}<0.01$; *** Significant at $\mathrm{P}<0.001$. 
Table 7. LSD and ANOVA results for spike density, grain yield, GS30 tissue $\mathrm{N}$, grain crude protein (at $120 \mathrm{~g} \mathrm{~kg}^{-1}$ grain moisture), and grain $\mathrm{N}$ yield for wheat grown with different pre-plant and topdress $\mathrm{N}$ treatments in Maine (ME) and Vermont (VT) in 2012 and 2013. VT-2012 GS30 tissue N and grain CP data were transformed ( $\lambda=-2$ and -4 , respectively). Back transformed values are in parentheses.

\begin{tabular}{|c|c|c|c|c|c|c|}
\hline Site-year & Treatment & $\begin{array}{l}\text { Spike density } \\
\left(\text { spike } \mathrm{m}^{-2} \text { ) }\right.\end{array}$ & $\begin{array}{l}\text { Grain yield } \\
\left(\mathrm{Mg} \mathrm{ha}^{-1}\right)\end{array}$ & $\begin{array}{l}\text { GS30 tissue } N \\
\left(\mathrm{~g} \mathrm{~kg}^{-1}\right)\end{array}$ & $\begin{array}{l}\text { Grain crude protein } \\
\left(\mathrm{g} \mathrm{kg}^{-1}\right)\end{array}$ & $\begin{array}{l}\text { Grain } N \text { yield } \\
\left(\mathrm{kg} \mathrm{ha}^{-1}\right)\end{array}$ \\
\hline \multirow[t]{11}{*}{ ME-2012 } & Check & $476^{c} \dagger$ & $3.57^{d}$ & $24.5^{b}$ & $99^{b}$ & $61^{d}$ \\
\hline & $\mathrm{PP}_{L} \ddagger$ & $445^{c}$ & $4.75^{b c}$ & $24.3^{b}$ & $96^{b}$ & $79^{c d}$ \\
\hline & $\mathrm{PP}_{H}$ & $544^{b c}$ & $4.55^{c}$ & $24.6^{b}$ & $99^{b}$ & $78^{c d}$ \\
\hline & $\mathrm{T} 1_{78}$ & $657^{a b}$ & $5.71^{a}$ & $34.2^{a}$ & $115^{a}$ & $113^{a}$ \\
\hline & $\mathrm{PP}_{L}+\mathrm{T}_{39}$ & $656^{a b}$ & $5.82^{a}$ & $32.8^{a}$ & $104^{b}$ & $104^{a b}$ \\
\hline & $\mathrm{PP}_{L}+\mathrm{T} 2_{39}$ & $553^{b c}$ & $5.35^{a b}$ & - & $98^{b}$ & $91^{b c}$ \\
\hline & $\mathrm{PP}_{H}+\mathrm{T} 2_{39}$ & $629^{a b}$ & $5.96^{a}$ & - & $101^{b}$ & $105^{a b}$ \\
\hline & $\mathrm{PP}_{L}+\mathrm{T} 1_{39}+\mathrm{T} 2_{39}$ & $739^{a}$ & $6.01^{a}$ & - & $103^{b}$ & $107^{a b}$ \\
\hline & Source of variation & & & AN & OVA & \\
\hline & Treatment & ** & $\star \star \star *$ & 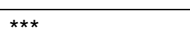 & * & 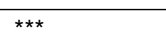 \\
\hline & $\mathrm{CV}, \%$ & 14.6 & 10.3 & 4.6 & 6.8 & 13.9 \\
\hline \multirow[t]{11}{*}{ ME-2013 } & Check & $333^{d}$ & $1.79^{c}$ & $32.5^{c}$ & $118^{c d}$ & $36^{b}$ \\
\hline & $\mathrm{PP}_{L}$ & $459^{b c}$ & $1.96^{b c}$ & $30.4^{c}$ & $119^{b c d}$ & $40^{b}$ \\
\hline & $\mathrm{PP}_{H}$ & $432^{c d}$ & $2.01^{b c}$ & $31.8^{c}$ & $117^{d}$ & $41^{b}$ \\
\hline & $\mathrm{T} 1_{78}$ & $569^{a b}$ & $2.77^{a}$ & $44.9^{a}$ & $130^{a}$ & $62^{a}$ \\
\hline & $\mathrm{PP}_{L}+\mathrm{T}_{39}$ & $484^{b c}$ & $2.87^{a}$ & $40.3^{b}$ & $116^{d}$ & $58^{a}$ \\
\hline & $\mathrm{PP}_{L}+\mathrm{T} 2_{39}$ & $505^{a b c}$ & $2.58^{a b}$ & - & $127^{a b}$ & $56^{a}$ \\
\hline & $\mathrm{PP}_{H}+\mathrm{T} 2_{39}$ & $535^{a b c}$ & $2.50^{a b}$ & - & $125^{a b c}$ & $54^{a}$ \\
\hline & $\mathrm{PP}_{L}+\mathrm{T} 1_{39}+\mathrm{T} 2_{39}$ & $606^{a}$ & $2.83^{a}$ & - & $130^{a}$ & $63^{a}$ \\
\hline & Source of variation & & & $\mathrm{ANN}$ & OVA & \\
\hline & Treatment & ** & $\star \star *$ & 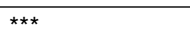 & $* *$ & *** \\
\hline & $\mathrm{CV}, \%$ & 16.1 & 18.3 & 6.5 & 4.3 & 16.3 \\
\hline \multirow[t]{11}{*}{ VT-2012 } & Check & 431 & $2.52^{b}$ & $0.101(32.0)$ & $8.04(106)^{d}$ & $46^{c}$ \\
\hline & $\mathrm{PP}_{L}$ & 558 & $2.96^{b}$ & $0.106(31.3)$ & $7.88(106)^{c d}$ & $54^{b c}$ \\
\hline & $\mathrm{PP}_{H}$ & 336 & $2.89^{b}$ & $0.098(32.3)$ & $7.45(108)^{b c d}$ & $49^{b c}$ \\
\hline & $\mathrm{T} 1_{78}$ & 552 & $4.31^{a}$ & $0.084(36.0)$ & $5.32(118)^{a}$ & $88^{a}$ \\
\hline & $\mathrm{PP}_{L}+\mathrm{T}_{39}$ & 696 & $3.12^{b}$ & $0.072(38.0)$ & $6.32(112)^{a b c}$ & $60^{b c}$ \\
\hline & $\mathrm{PP}_{L}+\mathrm{T} 2_{39}$ & 629 & $3.01^{b}$ & - & $6.14(113)^{a b}$ & $59^{b c}$ \\
\hline & $\mathrm{PP}_{H}+\mathrm{T} 2_{39}$ & 473 & $2.87^{b}$ & - & $5.40(118)^{a}$ & $63^{b}$ \\
\hline & $\mathrm{PP}_{L}+\mathrm{T} 1_{39}+\mathrm{T} 2_{39}$ & 535 & $3.07^{b}$ & - & $4.75(121)^{a}$ & $63^{b}$ \\
\hline & Source of variation & & & AN & OVA & \\
\hline & Treatment & ns & ** & ns & ** & $* * *$ \\
\hline & $\mathrm{CV}, \%$ & 30.3 & 16.2 & 21.7 & 17 & 16.9 \\
\hline \multirow[t]{11}{*}{ VT-2013 } & Check & $612^{a b}$ & $4.41^{b c}$ & 40.5 & $114^{d}$ & $87^{b}$ \\
\hline & $\mathrm{PP}_{L}$ & $604 \mathrm{ab}$ & $5.20^{a}$ & 41.6 & $129^{a b c}$ & $116^{a}$ \\
\hline & $\mathrm{PP}_{H}$ & $623^{a}$ & $4.19^{c}$ & 42.8 & $125^{c}$ & $90^{b}$ \\
\hline & $\mathrm{T} 1_{78}$ & $670^{a}$ & $4.22^{c}$ & 45.8 & $130^{a b c}$ & $95^{b}$ \\
\hline & $\mathrm{PP}_{L}+\mathrm{T} 1_{39}$ & $495^{b}$ & $4.27^{c}$ & 43.2 & $127^{b c}$ & $94^{b}$ \\
\hline & $\mathrm{PP}_{L}+\mathrm{T} 2_{39}$ & $725^{a}$ & $4.26^{c}$ & - & $129^{a b c}$ & $95^{b}$ \\
\hline & $\mathrm{PP}_{H}+\mathrm{T} 2_{39}$ & $689^{a}$ & $5.01^{a b}$ & - & $132^{a b}$ & $114^{a}$ \\
\hline & $\mathrm{PP}_{L}+\mathrm{T} 1_{39}+\mathrm{T} 2_{39}$ & $709^{a}$ & $4.02^{c}$ & - & $135^{a}$ & $93^{b}$ \\
\hline & Source of variation & & & AN & OVA & \\
\hline & Treatment & * & * & ns & $* * *$ & ** \\
\hline & $\mathrm{CV}, \%$ & 12.9 & 10.6 & 6.2 & 3.7 & 11.8 \\
\hline df & & 7 & 7 & 4 & 7 & 7 \\
\hline
\end{tabular}

* Significant at $P<0.05$; ** Significant at $P<0.01$; *** Significant at $P<0.001$; ns: not significant at $P<0.05$.

$\dagger$ Within column and site-year, treatment means with the same lower case letter are not significantly different at $\mathrm{P}<0.05$. $\ddagger \mathrm{PP}_{L}, 78 \mathrm{~kg} \mathrm{~N}^{-1}$ manure at pre-plant; $\mathrm{PP}_{H}, 117$ or $157 \mathrm{~kg} \mathrm{~N}^{-1}$ manure at pre-plant; $\mathrm{T}_{78}, 78 \mathrm{~kg} \mathrm{~N}^{-1}$ topdress at tillering; $\mathrm{T} 1_{39}, 39 \mathrm{~kg} \mathrm{~N} \mathrm{ha}^{-1}$ topdress at tillering; $\mathrm{T} 2_{39}, 39 \mathrm{~kg} \mathrm{~N} \mathrm{ha}^{-1}$ topdress at pre-stem extension. 
Impacts of the PP-only treatments on grain yield varied by site-year. Significant increases were observed in ME-2012 and VT-2013 when site-years were analyzed individually. In ME-2012, both PP-only treatments increased yields relative to the check by an average of $30 \%$. In VT2013 , only the $\mathrm{PP}_{L}$ treatment increased yields by $18 \%$. The $\mathrm{T} 1_{78}$ treatment increased grain yields by $20 \%$ in ME-2012, $41 \%$ in ME-2013, and 46\% in VT-2012, but reduced yields by $23 \%$ in VT-2013. The $\mathrm{PP}_{L}+\mathrm{T}_{39}$ treatment increased grain yields in ME-2012 and 2013 versus the $\mathrm{PP}_{L}$ treatment by 23 and $46 \%$, respectively, but reduced grain yields by $22 \%$ in VT-2013. The $\mathrm{PP}_{H}+\mathrm{T}_{39}$ treatment increased grain yields by 31 and $20 \%$ in ME-2012 and VT-2013, respectively, over the $\mathrm{PP}_{H}$ treatment. The $\mathrm{PP}_{L}+\mathrm{T}_{39}+\mathrm{T}_{39}$ treatment had no influence on grain yield in any site-year compared with $\mathrm{PP}_{L}+\mathrm{T}_{139}$ or $\mathrm{PP}_{L}+\mathrm{T}_{39}$ treatments.

Thousand kernel weights were measured for the ME site-years but are not presented because there were no significant treatment effects. Thousand kernel weights averaged $39.5 \mathrm{~g}$ in 2012 and $29.5 \mathrm{~g}$ in 2013, and were significantly correlated with grain yields $(r=0.48, p<0.01$ and $r=0.59, p<0.001$ for 2012 and 2013, respectively).

\subsection{GS30 Tissue N, Grain Crude Protein, and Grain N Yield}

Treatment effects on GS30 wheat tissue N concentrations were evident only in $\mathrm{ME}$ and were restricted to tillering $\mathrm{N}$ additions; $\mathrm{N}$ applied at pre-plant had no significant effects (Table 7). Compared with $\mathrm{PP}_{L}$, the $\mathrm{T} 1_{78}$ treatment increased tissue $\mathrm{N}$ by $44 \%$ on average and the $\mathrm{PP}_{L}+\mathrm{T}_{39}$ produced a $34 \%$ average increase.

Grain CP averaged 102, 123, 113, and $128 \mathrm{~g} \mathrm{~kg}^{-1}$ in ME-2012, ME-2013, VT-2012, and VT-2013, respectively (Table 7). The PP-only treatments had no significant effect on CP except in VT-2013 where the $78 \mathrm{~kg} \mathrm{~N}^{-1}$ rate increased CP by $13 \%$ as compared with the check. The $\mathrm{T}_{78}$ treatment increased CP compared with the $\mathrm{PP}_{L}$ and $\mathrm{PP}_{H}$ treatments by an average of $14 \%$ at the ME sites and by $11 \%$ in VT-2012, but had no effect in VT-2013. The $\mathrm{PP}_{L}+$ $\mathrm{T}_{39}$ treatment produced no measurable increases in CP and the $\mathrm{PP}_{L}+\mathrm{T} 2_{39}$ treatment increased CP in VT-2012 by $7 \%$ compared with the $\mathrm{PP}_{L}$ treatment. The $\mathrm{PP}_{H}+\mathrm{T}_{39}$ treatment increased CP in three of four site-years compared with the $\mathrm{PP}_{H}$ treatment by 7, 9, and 6\% in ME-2013, VT2012, and VT-2013, respectively. The $\mathrm{PP}_{L}+\mathrm{T} 1_{39}+\mathrm{T} 2_{39}$ treatment increased CP only in ME-2013 by $12 \%$ compared with the $\mathrm{PP}_{L}+\mathrm{T} 1_{39}$ treatment.

Grain N yield results were similar to grain yield results with two exceptions (Table 7). In ME-2012, the $\mathrm{PP}_{H}$ treatment did not increase grain $\mathrm{N}$ yield compared with the check, and in ME-2013, the $\mathrm{PP}_{L}+\mathrm{T}_{39}$ treatment increased grain $\mathrm{N}$ yield by $40 \%$ compared with the $\mathrm{PP}_{L}$ treatment.

\subsection{In-season Tests}

Tiller density was a better predictor of grain yield $(r=0.52$, $p<0.001$; Figure 1$)$ than tissue-N at GS30 $(r=0.09$, $p=0.426$; data not show) when compared across siteyears. The residuals from the regression line in Figure 1 were not influenced by treatment $(p=0.175)$.

Correlations were weak when analyzed by site-year (data not shown) likely due to limited tiller range and variability within site-year. Tiller densities in ME-2012, for example, ranged from 1184 to 1668 tillers $\mathrm{m}^{-2}$ with a standard deviation of 149 tillers $\mathrm{m}^{-2}$. Tissue $\mathrm{N}$ at GS30 was a good predictor of CP $(r=0.75, p<0.001$; Figure 2$)$. The residuals from the regression line in Figure 2 were influenced by treatment $(p=0.005)$, indicating that additional variance in the model was explained by the treatments.

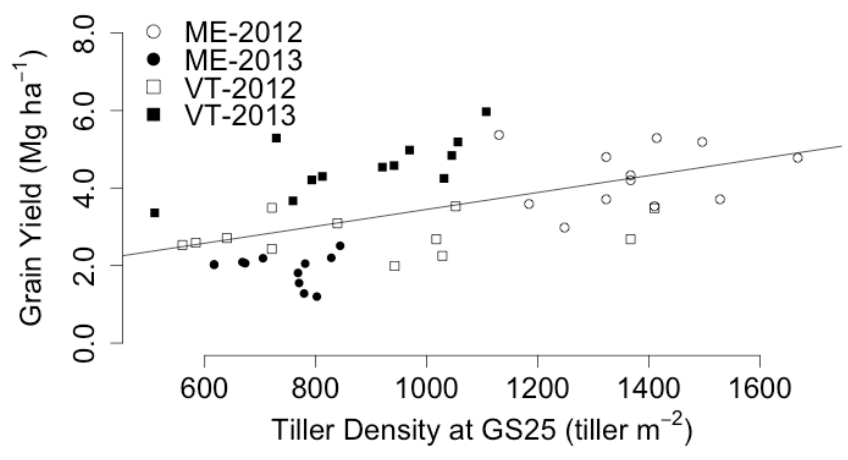

Figure 1. Correlations between tiller density at GS25 and grain yield in Maine (ME) and Vermont (VT) in 2012 and 2013 across different pre-plant $N$ treatments $(y=0.0021 x$ $+1.2668 ; r=0.52 ; p<0.001)$. Data are treatment means from each site year. The standard error of the regression coefficients was 0.540 and 0.001 for $\beta_{0}$ and $\beta_{1}$, respectively.

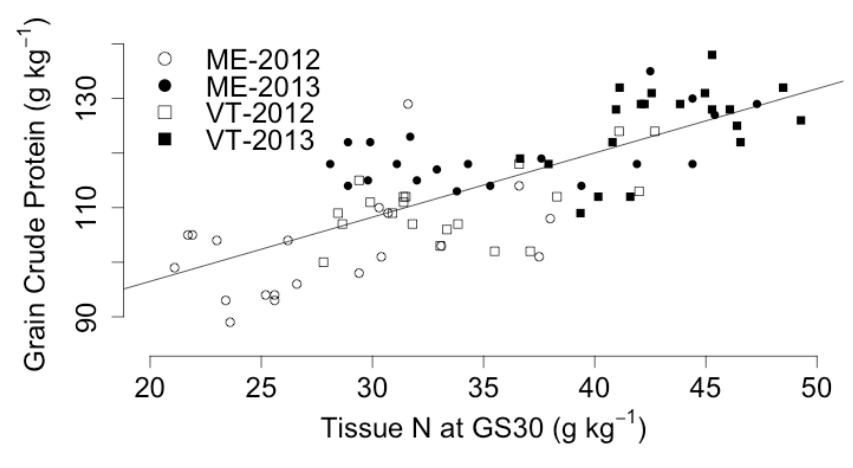

Figure 2. Correlation between tissue $\mathrm{N}$ and crude protein in Maine (ME) and Vermont (VT) in 2012 and 2013 across different pre-plant and topdress $N$ treatments $(y=1.176 x$ $+72.963 ; r=0.75 ; p<0.001)$. Data are treatment means from each site year. The standard error of the regression coefficients was 4.164 and 0.116 for $\beta_{0}$ and $\beta_{1}$, respectively.

\section{Discussion}

\subsection{Site-year Effects}

Differences in growing conditions among the four site-years made it difficult to draw general conclusions and recom- 
mendations based on the effects of $\mathrm{N}$ treatment. In both ME-2012 and VT-2013, favorable growing conditions supported high yield potentials, as evidenced by the high yields in the check, although varying levels of $\mathrm{N}$ availability from soil \%OM may have caused different treatment responses between these two site-years. Where \%OM was low (ME2012), all $\mathrm{N}$ treatments produced positive and substantial increases in grain yield. The only treatment to increase $\mathrm{CP}$ was the highest single topdress application. When an increase in yield occurs, it is often accompanied by an increase in grain $\mathrm{N}$ yield but not necessarily $\mathrm{CP}$ as the increase in carbohydrates dilutes the $\mathrm{N}[2,41]$. In contrast, where \%OM was high (VT-2013), N treatments produced fewer positive yield responses but more increases in CP. While soil nitrate was not measured in this study, the relatively high \%OM measured at this site suggests greater soil $\mathrm{N}$ supply $[42,43]$. This site-year also was the only one to demonstrate an increase in CP from the PP-only treatments. These results are congruent with a study by Woodward and Bly [4] showing that $\mathrm{N}$ must be of sufficient amount and appropriately timed to support positive responses in both yield and CP. Terman et al. [10] found that under high soil nitrate conditions ( $>67 \mathrm{~kg} \mathrm{ha}^{-1} \mathrm{NO}_{3}-\mathrm{N}$ ), additional $\mathrm{N}$ applied to hard red winter wheat produced an increase in grain protein content but low or absent responses in grain yield. Similarly, Frederick and Marshall [44] found early spring topdressing to soft red winter wheat on soils with high $\mathrm{N}$ reserves decreased grain yields by reducing kernel weight or productive tillers below the level necessary for optimal yield.

In ME-2013 and VT-2012, the check treatment yields suggest reduced yield potentials. In ME-2013, yield potential was likely limited by observed weed and disease pressure resulting from a lack of rotation. It was less likely the preceding mustard affected wheat yield because the mustard crop accumulated relatively little biomass before incorporation and stand counts show no effect as compared with prior years when wheat followed fallow (data not shown). Nonetheless, these factors did not limit the responsiveness of this site to $\mathrm{N}$ treatments. Treatment effects were observed for both grain yield and CP. As a consequence of the low yields, CP potential was relatively high, which was consistent with the tradeoff between yield and protein reported by others $[9,11]$. All treatments exceeded $110 \mathrm{~g} \mathrm{~kg}^{-1} \mathrm{CP}$ and nearly all those receiving topdress $\mathrm{N}$ had CP levels above $120 \mathrm{~g} \mathrm{~kg}^{-1}$. In VT-2012, it was possible that heavy rainfall, occurring 2 days after the pre-plant applications, may have been a contributing factor to the relatively low grain yield potential and limited yield response to $\mathrm{N}$. Only the highest topdress $\mathrm{N}$ rate $\left(\mathrm{T}_{78}\right)$ produced a yield response, whereas more treatment responses were observed for $\mathrm{CP}$.

\subsection{Nitrogen Treatment Effects}

The PP-only treatments improved yields at three of four site-years (when ME site-years were analyzed together) but were less likely to produce an increase in CP. These results are congruent with others who have found that applications at the pre-plant timing alone do not supply an adequate amount of late-season available $\mathrm{N}$ to enhance $\mathrm{CP}$ in winter wheat $[3,45]$. At the majority of site-years, it was possible that the amount or timing of mineralization from the organic $\mathrm{N}$ fraction of manure was insufficient to support protein production. The VT-2013 site was the exception because high $\% O M$ may have impacted yield-CP dynamics as previously described. These results support findings that matching the $\mathrm{N}$ availability of organic $\mathrm{N}$ sources with the periods of high crop $\mathrm{N}$ demand presents a major challenge for organic bread wheat producers [14].

The $\mathrm{T}_{78}$ treatment produced increases in both yield and $\mathrm{CP}$ in the majority of site-years suggesting that the springtime application was better matched with crop $\mathrm{N}$ demand than the pre-plant application timing. This enhanced plant $\mathrm{N}$ uptake at soft dough and ANR over the PP-only treatment. Increases in both grain yield and CP also suggest available $\mathrm{N}$ was in excess of yield requirements and was sufficient to increase CP $[11,46]$. It should be noted that $\mathrm{N}$ application timing and source are confounded in these comparisons and the difference in $\mathrm{N}$ source (manure vs. CN) could also be a factor in the observed effects.

Treatments receiving a topdress application often showed a yield and CP advantage over the PP-only treatments. The $\mathrm{PP}_{L}+\mathrm{T}_{39}$ treatment produced some measurable increases in yields and plant $\mathrm{N}$ uptake compared with the PP-only treatments but never produced a measurable increase on CP. More frequent effects on yield and CP were found with the $\mathrm{PP}_{H}+\mathrm{T}_{29}$ treatment versus the $\mathrm{PP}_{H}$ comparison possibly because greater mineralization of $\mathrm{N}$ from the $\mathrm{PP}_{H}$ treatment may have been adequate to support CP. The timing of supplemental $\mathrm{N}$ applied in the $\mathrm{PP}_{L}+\mathrm{T}_{139}$ and $\mathrm{PP}_{L}+\mathrm{T}_{29}$ treatments had no influence on yield and CP results likely because the applications were too close in time to cause differences. The application at T2 was relatively early compared to other studies that showed topdress applied later, at flag leaf (GS39) and boot (GS45), were more effective at increasing CP than the T1 application [3].

Nitrogen applied at both T1 and T2 did not increase yields relative to supplemental $\mathrm{N}$ applied at $\mathrm{T} 1$ or $\mathrm{T} 2$. The fact that $\mathrm{N}$ applied at both timings produced among the highest yields in ME, indicates two topdress applications were in excess of that required to reach a yield plateau. Interestingly, the opposite effect occurred in VT; treatment yields with two topdress applications were equivalent to the check and among the lowest of all treatments. The VT data suggests this response was attributed to the aforementioned site factors. Application timing may have also been a factor in the observed effects on CP. Two $\mathrm{N}$ applications increased CP relative to the $\mathrm{T} 1$ application at two of four site-years but never increased CP relative to the T2 application. Greater differences in CP may have occurred if the second application of topdress were delayed to GS45 or later [41].

These findings indicate that when yield potential was high, treatments that included topdress $\mathrm{N}$ generally produced CP greater than the $100 \mathrm{~g} \mathrm{~kg}^{-1}$ threshold considered 
sufficient by local artisan bakers in our region. With this in mind, the costs of applying organic-approved sources of $\mathrm{N}$ must be compared against the crop value. Chilean nitrate is cheaper (US\$229 ha $\mathrm{ha}^{-1}$ ) than other organic-approved sources of $\mathrm{N}$ though it is not allowed in Canada and Europe and may be prohibited in the future under the US National Organic Standards Board. Other topdress sources, such as dehydrated poultry litter, are more expensive (US\$ 459 $\mathrm{ha}^{-1}$ ) and may have lower $\mathrm{N}$ availability compared with the soluble $\mathrm{CN}$ [3], which may reduce its efficacy.

\subsection{In-season Test: Tiller Density}

Results indicated that tiller densities can be a predictor of grain yield but a wider range of densities is needed to better understand the utility of this measurement as a decision tool. When tiller densities were below the 1000 tillers $\mathrm{m}^{-2}$ threshold established by Scharf and Alley [47], there was not a yield penalty for delaying supplemental topdressing from GS25 to GS30 in ME-2013, VT-2012, and VT-2013. Similarly, when average tiller densities were $<1000$ tillers $\mathrm{m}^{-2}$, there was no penalty for supplying $\mathrm{N}$ earlier at GS25 [6]. In fact, only the $\mathrm{PP}_{L}+\mathrm{T}_{139}$ and $\mathrm{PP}_{L}+\mathrm{T} 1_{39}+\mathrm{T} 2_{39}$ treatments in the ME site-years enhanced yields over the $\mathrm{PP}_{L}$ whereas the $\mathrm{PP}_{L}+\mathrm{T} 2_{39}$ treatment did not. Nitrogen topdress rates of 39 and 78 total $\mathrm{kg} \mathrm{N} \mathrm{ha}^{-1}$ applied in this study were slightly above the range recommended of approximately 30 to $56 \mathrm{~kg} \mathrm{~N} \mathrm{ha}^{-1}$ for densities $<1000$ tillers $\mathrm{m}^{-2}$ [6]. It is possible that tiller densities in this study were not low enough to produce the measurable yield differences between the $\mathrm{PP}_{L}+\mathrm{T}_{39}$ and $\mathrm{PP}_{L}+\mathrm{T} 2_{39}$ applications that others have found. For instance, in a study with non-organically managed no-till winter wheat, Weisz et al. [48] showed that when tiller densities were below 550 tillers $\mathrm{m}^{-2}$, treatments with supplemental N applied at GS25 and split applied between GS25 and GS30 produced greater yields than the treatment with supplemental N at GS30. Therefore, fully evaluating topdressing timing effects at the threshold established by Scharf and Alley [47] was limited by the fact that tiller densities at most site-years were adequate but never well below the threshold $(738,906$, and 890 tillers $\mathrm{m}^{-2}$ in ME-2013, VT-2012, and VT-2013, respectively) and exceeded 1000 tillers $\mathrm{m}^{-2}$ in just ME-2012 (1371 tillers $\mathrm{m}^{-2}$ ). The PP-only treatments did not produce statistically different tiller densities and an effort to capture a wider range through seeding rates and dates may be needed. For instance, Weisz et al. [48] found that different seeding rates and dates produced a range of 162 to 1774 tillers $\mathrm{m}^{-2}$ in soft red winter wheat.

\subsection{In-season Test: Tissue Nitrogen}

Tissue $\mathrm{N}$ values in this study ranged from 24.3 to $45.8 \mathrm{~g}$ $\mathrm{kg}^{-1}$ and were similar to the $>20.0$ to $<50.0 \mathrm{~g} \mathrm{~kg}^{-1}$ values reported by Baethgen and Alley [26] for soft winter wheat. $A$ stronger correlation between tissue $\mathrm{N}$ and $\mathrm{CP}$ than between tissue $\mathrm{N}$ and yield suggests this test may be useful to guide
$\mathrm{N}$ management for CP even though other studies do not explore this purpose. Using the slope of the regression line (Figure 2) the critical level for achieving CP of $120 \mathrm{~g} \mathrm{~kg}^{-1}$ was a tissue $\mathrm{N}$ concentration of $40.0 \mathrm{~g} \mathrm{~N} \mathrm{~kg}^{-1}$. This value aligns with the critical value of $39.5 \mathrm{~g} \mathrm{~N} \mathrm{~kg}^{-1}$ reported by Baethgen and Alley [26] for achieving 90\% relative yield without further fertilization. The critical level was met at the site-years with the highest overall CPs. Specifically, delaying topdress $\mathrm{N}$ until GS25 in ME-2013 and all N treatments in VT-2013 met the critical level (Table 7). In site-years with low overall CPs such as ME-2012 and VT-2012, the critical level was never met but individual cases suggest the tissue $\mathrm{N}$ test has the predictive power to obtain the desired $\mathrm{CP}$ response.

In ME-2012, low tissue $\mathrm{N}$ concentrations $\left(24.4 \mathrm{~g} \mathrm{~kg}^{-1}\right.$ for the PP-only treatments; $32.8 \mathrm{~g} \mathrm{~kg}^{-1}$ for $\mathrm{PP}_{L}+\mathrm{T} 1_{39}$ ) implied the need for approximately 120 and $78 \mathrm{~kg} \mathrm{~N} \mathrm{ha}^{-1}$, respectively, at GS30 according to Alley et al. [6]. The rate of $39 \mathrm{~kg} \mathrm{~N} \mathrm{ha}^{-1}$ applied at GS30 was possibly inadequate because the desired CP was never met. Conversely, in VT-2012, the $39 \mathrm{~kg} \mathrm{~N}^{-1}$ applied at GS30 for the same treatment $\left(\mathrm{PP}_{L}+\mathrm{T} 2_{39}\right)$ aligned more with the rate recommended by the tissue test $\left(47 \mathrm{~kg} \mathrm{~N} \mathrm{ha}^{-1}\right)$ and was adequate to meet the desired CP.

These results suggest that testing various $\mathrm{N}$ application rates at GS30 against the measured tissue $\mathrm{N}$ values would broaden understanding of the rates need to maximize CP. Beyond applying a sufficient $\mathrm{N}$ rate, $\mathrm{N}$ application timing may have been an influential factor in the aforementioned results such that the $\mathrm{N}$ applied at GS30 may have been too early to increase CP. Others have found later applications of $\mathrm{N}$ at the boot stage (GS45) were more effective at increasing $\mathrm{CP}$ in hard red winter wheat than applications at or prior to GS30 [3,22,49]. However, Gooding et al. [50] noted foliar urea applied at or soon after anthesis increased CP but post anthesis applications pose higher risk of $\mathrm{N}$ loss. For an organic producer, the threshold at which tissue $\mathrm{N}$ testing is relevant should be based on the producer's means to apply an $\mathrm{N}$ source later in the season as well as their access to an organic approved $\mathrm{N}$ source with rapid $\mathrm{N}$ availability. As discussed by Mallory and Darby [3], while topdressing could be a good strategy for organic winter bread wheat producers, further evaluation of topdress $\mathrm{N}$ sources is needed. Lastly, measuring tissue $\mathrm{N}$ concentrations beyond GS30 may reveal that late-season mineralization from organic $\mathrm{N}$ attributes to $\mathrm{CP}$, but studies addressing this area are lacking. Brown et al. [41] and Brown and Petrie [45] reported that flag leaf total $\mathrm{N}$ taken at early heading or anthesis (GS50-60) was better related to $\mathrm{CP}$ at harvest than samples collected earlier because the majority of plant $\mathrm{N}$ uptake occurs by flag leaf emergence.

\section{Conclusions}

The primary objective of this study was to analyze split $\mathrm{N}$ application regimes and in-season tests to guide $\mathrm{N}$ applications for organic production. The PP-only treatments were 
unreliable for producing market quality bread wheat. The $\mathrm{T} 1_{78}$ treatment produced the highest yield and $\mathrm{CP}$, except for one case, but delaying all $\mathrm{N}$ application until spring is challenging in terms of the feasibility of applying a costeffective fresh animal or green manure $\mathrm{N}$ or the cost of easily applied pelletized organic $\mathrm{N}$ sources. Topdressing supplemental $\mathrm{N}$ was effective at increasing yield and $\mathrm{CP}$ when preceded by the $\mathrm{PP}_{H}$ application. The $\mathrm{PP}_{L}+\mathrm{T}_{39}+$ $\mathrm{T} 2_{39}$ treatment generally did not enhance results compared with single topdress application at T1 or T2. Responses to added $\mathrm{N}$ were variable among site-years and influenced by yield potential and soil \%OM. In-season tests hold promise as decision tools for organic winter bread wheat production but additional evaluation and calibration is needed. Future studies should include a variety of organic-approved and locally available pre-plant and topdress sources, a wider range of background tiller densities and topdress $\mathrm{N}$ rates, and perform tissue testing at growth stages beyond GS30, but prior to GS60.

\section{Acknowledgements}

The authors would like to thank Tom Molloy, Erica Cummings, and the MAFES Analytical Laboratory for their technical assistance. This work was supported by the USDA National Institute of Food and Agriculture Organic Agriculture Research and Extension Initiative under Agreement no. 2009-51300-05594, "Enhancing Farmers' Capacity to Produce High Quality Organic Bread Wheat", and by Hatch Grant no. ME08001-10 from the USDA National Institute of Food and Agriculture.

\section{References and Notes}

[1] Payne API, Holt LM, Jackson EA, Law CN, Damania AB, Lane M. Wheat storage proteins: Their genetics and their potential for manipulation by plant breeding [and discussion]. Philosophical Transactions of the Royal Society of London. 1984;304(1120):359-371. doi:10.1098/rstb.1984.0031.

[2] Gooding MJ, Cannon ND, Thompson AJ, Davies WP. Quality and value of organic grain from contrasting breadmaking wheat varieties and near isogenic lines differing in dwarfing genes. Biological Agriculture \& Horticulture. 1999;16(4):335-350. doi:10.1080/01448765.1999.9755237.

[3] Mallory EB, Darby H. In-season nitrogen effects on organic hard red winter wheat yield and quality. Agronomy Journal. 2013;105(4):11671175. doi:10.2134/agronj2012.0447.

[4] Woodard HJ, Bly A. Relationship of nitrogen management to winter wheat yield and grain protein in South Dakota. Journal of Plant Nutrition. 1998;21(2):217-233. doi:10.1080/01904169809365397.

[5] Fowler DB. Crop nitrogen demand and grain protein concentration of spring and winter wheat. Agronomy Journal. 2003;95:260-265. doi:10.2134/agronj2003.2600.

[6] Alley MM, Scharf P, Brann DE, Baethgen WE, Hammons JL. Nitrogen management for winter wheat: Principles and recommendations [Online]; 2009. Available from: http://pubs.ext.vt.edu/424/424-026/424026.html.

[7] Johansson E, Prieto-Linde ML, Jönsson JÖ. Effects of wheat cultivar and nitrogen application on storage protein composition and breadmaking quality. Cereal Chemistry. 2001;78(1):19-25. doi:10.1094/CCHEM.2001.78.1.19.

[8] Eilrich GL, Hageman RH. Nitrate reductase activity and its relationship to accumulation of vegetative and grain nitrogen in wheat (Triticum aestivum L.). Crop Science. 1973;13:59-66. doi:10.2135/cropsci1973.0011183X001300010018x.

[9] Fowler DB, Brydon J, Darroch BA, Entz MH, Johnston AM. Environment and genotype influence on grain protein concentration of wheat and rye. Agronomy Journal. 1990;82(4):655-664. doi:10.2134/agronj1990.00021962008200040002x.

[10] Terman GL, Ramig RE, Dreier AF, Olson RA. Yieldprotein relationships in wheat grain, as affected by nitrogen and water. Agronomy Journal. 1969;61:755-759. doi:10.2134/agronj1969.00021962006100050031x.

[11] Terman GL. Yields and protein content of wheat grain as affected by cultivar, $\mathrm{N}$, and environmental growth factors. Agronomy Journal. 1979;71(3):437-440. doi:10.2134/agronj1979.00021962007100030014x.

[12] Brown BD, Petrie S. Irrigated hard winter wheat response to fall, spring, and late season applied nitrogen. Field Crops Research. 2006;96(2-3):260-268. doi:10.1016/j.fcr.2005.07.011.
[13] Doltra J, Lægdsmand M, Olesen JE. Cereal yield and quality as affected by nitrogen availability in organic and conventional arable crop rotations: A combined modeling and experimental approach. European Journal of Agronomy. 2011;34(2):83-95. doi:10.1016/j.eja.2010.11.002.

[14] Bilsborrow P, Cooper J, Tétard-Jones C, Średnicka-Tober D, Barański $M$, Eyre $M$, et al. The effect of organic and conventional management on the yield and quality of wheat grown in a longterm field trial. European Journal of Agronomy. 2013;51:71-80. doi:10.1016/j.eja.2013.06.003.

[15] Dawson JC, Huggins DR, Jones SS. Characterizing nitrogen use efficiency in natural and agricultural ecosystems to improve the performance of cereal crops in low-input and organic agricultural systems. Field Crops Research. 2008;107(2):89-101. doi:10.1016/j.fcr.2008.01.001.

[16] Agehara S, Warncke DD. Soil moisture and temperature effects on nitrogen release from organic nitrogen sources. Soil Science Society of America Journal. 2005;69(6):1844-1855. doi:10.2136/sssaj2004.0361.

[17] Olesen JE, Askegaard M, Rasmussen IA. Winter cereal yields as affected by animal manure and green manure in organic arable farming. European Journal of Agronomy. 2009;30(2):119-128. doi:10.1016/j.eja.2008.08.002.

[18] National Organic Program. Final Rule: 7 CFR Part 205. Washington, DC, USA: US Department of Agriculture-Agricultural Marketing Service; 2013. Available from: https://www.ams.usda.gov/rulesregulations/organic.

[19] Wuest SB, Cassman KG. Fertilizer-nitrogen use efficiency of irrigated wheat: I. Uptake efficiency of preplant versus lateseason application. Agronomy Journal. 1992;84(4):682-688. doi:10.2134/agronj1992.00021962008400040028x.

[20] Scharf PC, Alley MM. Spring nitrogen on winter wheat: I. Farmer-field validation of tissue test-based rate recommendations. Agronomy Journal. 1993;85:1181-1186. doi:10.2134/agronj1993.00021962008500060017x.

[21] White AEM, Wilson FEA. Responses of grain yield, biomass and harvest Index and their rates of genetic progress to nitrogen availability in ten winter wheat varieties. Irish Journal of Agriculture and Food Research. 2006;45:85-101.

[22] Kratochvil RJ, Harrison MR, Pearce JT, Conover KJ, Sultenfuss $M$. Nitrogen management for Mid-Atlantic hard red winter wheat production. Agronomy Journal. 2005;97(1):257-264. doi:10.2134/agronj2005.0257.

[23] Sowers E, Pan L, Miller BC, Smith JL. Nitrogen use efficiency of split nitrogen applications in soft white winter wheat. Agronomy Journal. 1994;86(6):942-948. doi:10.2134/agronj1994.00021962008600060004x.

[24] Papakosta DK, Gagianas AA. Nitrogen and dry matter accu- 
mulation, remobilization, and losses for mediterranean wheat during grain filling. Agronomy Journal. 1991;83(5):864-870. doi:10.2134/agronj1991.00021962008300050018x.

[25] Zadoks JC, Chang TT, Konzak CF. A decimal code for the growth stages of cereals. Weed Research. 1974;14(6):415-421. doi:10.1111/j.1365-3180.1974.tb01084.x.

[26] Baethgen WE, Alley MM. Optimizing soil and fertilizer nitrogen use by intensively managed winter wheat II. Critical levels and optimum rates of nitrogen fertilizer. Agronomy Journal. 1989;81:120-125. doi:10.1080/00103620802004052.

[27] Rasmussen C, Dunn M, Ristow P, Shepherd T, Czymmek K. Manure value, cost and time management calculator, user's manual. Ithaca, NY, USA: Cornell University; 2010. Available from: http://nmsp.cals. cornell.edu/projects/curriculum/Manure/Manure_UserManual.pdf.

[28] Jokela B, Magdoff F, Barlett S, Bosworth S, Ross D. Nutrient recommendations for field crops in Vermont; 2004. Available from: http://pss. uvm.edu/vtcrops/articles/VT_Nutrient_Rec_Field_Crops_1390.pdf.

[29] Gale ES, Sullivan DM, Cogger CG, Bary AI, Hemphill DD, Myhre E. Estimating plant-available nitrogen release from manures, composts, and specialty products. Journal of Environmental Quality. 2006;35(6):2321-2332. doi:10.2134/jeq2006.0062.

[30] Sodium nitrate use in organic crop production. NOP Notice 12-1. Washington, DC, USA: US Department of Agriculture-Agricultural Marketing Service; 2012. Available from: http://www.ams.usda.gov/ AMSv1.0/getfile?dDocName=STELPRDC5100372.

[31] Hoskins BR. Soil testing handbook for professionals in agriculture, horticulture, nutrients and residuals management. 3rd ed. Orono, ME, USA: Maine Forestry and Agricultural Experiment Station; 1997.

[32] Approved methods of analysis, 11th ed. Method 46-30.01. NitrogenCrude protein combustion method. AACC International; 2010. Available from: http://methods.aaccnet.org/summaries/46-30-01.aspx.

[33] Long DS, Engel RE, Siemens MC. Measuring grain protein concentration with in-line near infrared reflectance spectroscopy. Agronomy Journal. 2008;100(2):247-252. doi:10.2134/agronj2007.0052.

[34] R Core Team. R: A language and environment for statistical computing. Vienna, Austria; 2015. Available from: http://www.R-project.org/.

[35] Pinheiro J, Bates D, DebRoy S, Sarkar D, R Core Team. nlme: Linear and Nonlinear Mixed Effects Models; 2015. R package version 3.1-120. Available from: http://CRAN.R-project.org/package=nlme.

[36] Fox J, Weisberg S. An $\{R\}$ companion to applied regression, Second Edition. Thousand Oaks, CA, USA: Sage; 2011. Available from: http://socserv.socsci.mcmaster.ca/jfox/Books/Companion.

[37] Venables WN, Ripley BD. Modern applied statistics with S-Plus. 4th ed. New York, NY, USA: Springer; 2002.

[38] Torsten Hothorn FB, Westfall P. Simultaneous Inference in General Parametric Models. Biometrical Journal. 2008;50(3):346-363. doi:10.1002/bimj.200810425.

[39] Schindler FV, Knighton RE. Fate of fertilizer nitrogen applied to corn as estimated by the isotopic and difference methods. Soil Science Society of America Journal. 1999;63(6):1734-1740. doi:10.2136/sssaj1999.6361734x.

[40] Mallory E, Darby H, Molloy T, Cummings E. Maine and Vermont organic winter wheat variety trial results 2010- 2013. Orono, ME, USA: University of Maine Cooperative Extension and University of Vermont Cooperative Extension; 2015. Available from: https://extension.umaine.edu/localwheat/wpcontent/uploads/sites/73/2015/11/2010-2013-Organic-WinterWheat-Variety-Trial-Results-\%E2\%80\%93-Maine-Vermont.pdf.

[41] Brown B, Westcott M, Christensen N, Pan B, Stark J. Nitrogen management for hard wheat protein enhancement. Pullman, WA, USA Washington State University Cooperative Extension; 2005. Available from: http://plantbreeding.wsu.edu/pnw0578.pdf.

[42] Petersen SO, Schjønning P, Olesen JE, Christensen S, Christensen BT. Sources of nitrogen for winter wheat in organic cropping systems. Soil Science Society of America Journal. 2013;77(1):155 doi:10.2136/sssaj2012.0147.

[43] Ros GH. Predicting soil $\mathrm{N}$ mineralization using organic matter fractions and soil properties: A re-analysis of literature data. Soil Biology and Biochemistry. 2012;45:132-135. doi:10.1016/j.soilbio.2011.10.015.

[44] Frederick JR, Marshall HG. Grain yield and yield components of soft red winter wheat as affected by management practices. Agronomy Journal. 1985;77:495-499. doi:10.2134/agronj1985.00021962007700030030x.

[45] Brown BD, Petrie S. Irrigated hard winter wheat response to fall, spring, and late season applied nitrogen. Field Crops Research. 2006;96(3):260-268. doi:10.1016/j.fcr.2005.07.011.

[46] Huggins D, Pan W, Smith J. Yield, protein and nitrogen use efficiency of spring wheat: Evaluating field-scale performance. Pullman, WA, USA: Center for Sustaining Agriculture and Natural Resources, Washington State University; 2010.

[47] Scharf PC, Alley MM. Spring nitrogen on winter wheat: II. A flexible multicomponent rate recommendation system. Agronomy Journal. 1993;25(6):1186-1192. doi:10.2134/agronj1993.00021962008500060018x.

[48] Weisz R, Crozier CR, Heiniger RW. Optimizing nitrogen application timing in no-till soft red winter wheat. Agronomy Journal. 2001;93:435-442. 2. doi:10.2134/agronj2001.932435x. 2.

[49] Alcoz MM, Hons FM, Haby VA. Nitrogen fertilization timing effect on wheat production, nitrogen uptake efficiency, and residual soil nitrogen. Agronomy Journal. 1993;85:1198-1203. 6. doi:10.2134/agronj1993.00021962008500060020x. 6

[50] Gooding MJ, Gregory PJ, Ford KE, Ruske RE. Recovery of nitrogen from different sources following applications to winter wheat at and after anthesis. Field Crops Research. 2007;100(2):143-154. doi:10.1016/j.fcr.2006.06.002. 